\title{
PERKEMBANGAN PENDIDIKAN AL-JAM'IYATUL WASHLIYAH PADA MASA REFORMASI DI KOTA MEDAN
}

\author{
Oleh: \\ Hafnita Sari Dewi Lubis \\ Imro Atur Rusydah
}

\begin{abstract}
ABSTRAK
Penelitian ini bertujuan untuk mengetahui latar belakang berdirinya Organisasi AlJam'iyatul Washliyah, terutama dalam peranan Al-Jam'iyatul Washliyah mengembangkan pendidikan di Kota Medan pada masa Reformasi dalam kurun waktu 1998-2019, khususnya dibidang Pendidikan Umum. Penelitian ini menggunakan pendekatan historis. Untuk mendapatkan sumber penelitian, peneliti mengandalkan penelitian lapangan (field research) dan kepustakaan (library research). Dari hasil penelitian dapat diketahui bahwa Organisasi Al-Jam'iyatul Washliyah lahir pertama kali di Medan dengan tujuan menghubungkan dan mempertalikan umat Islam pada tanggal 30 November 1930. Al-Jam'iyatul Washliyah menunjukkan komitmen yang sangat tinggi dilihat dari usaha dan peranannya dengan cara mendirikan lembaga-lembaga pendidikan dalam semua jenis jenjang pendidikan. Pada masa awal didirikan lembaga pendidikan AlJam'iyatul Washliyah lebih terfokus kepada pendidikan agama saja. Namun setelah perkembangannya, Al-Jam'iyatul Washliyah juga mendirikan lembaga pendidikan umum, mulai dari pendidikan pra sekolah sampai pendidikan tinggi. Pada masa Reformasi, lembaga-lembaga pendidikan umum yang didirikan Al-Jam'iyatul Washliyah telah mengalami perkembangan terutama dari sisi fasilitas, baik dari jumlah unit bangunan sekolah, maupun materi pelajaran yang dimiliki pada program pendidikan. Tidak dapat dipungkiri, bahwa kemajuan pendidikan di Kota Medan juga salah satu peran organisasi Al-Washliyah.
\end{abstract}

Kata Kunci : Al-Jam'iyatul Washliyah, Pendidikan, Reformasi 


\section{PENDAHULUAN}

Masa reformasi sangat menarik untuk melihat kembali posisi pendidikan Islam dan memotret perkembangan pada lembaga pendidikan Islam. Sedikitnya ada dua alasan untuk fokus terhadap eksistensi pendidikan Islam era reformasi. Pertama, Undang-Undang Nomor 20 tahun 2003 tentang Sistem Pendidikan Nasional memberikan ruang yang cukup luas bagi pengembangan Institusi pendidikan agama, khususnya pendidikan Islam. Kedua, kondisi lembaga pendidikan Islam di Indonesia yang sebagian besar masih bersifat tradisional dan hanya dipandang sebagai pendidikan kelas dua, menyebabkan lembaga pendidikan Islam kalah bersaing dengan lembaga pendidikan lainnya.

Sebelum reformasi, pendidikan Al-Washliyah sendiri masih kalah bersaing dengan pendidikan negeri atau pendidikan dari organisasi lain, apalagi pendidikan Al-Washliyah pada saat itu masih bersifat tradisional dan masih dipandang sebagai pendidikan kelas dua. Dengan dilihat dari jumlah siswa dan orang tua yang memiliki minat untuk memasukkan anaknya ke sekolah Al-Washliyah, bangunan sekolah dan fasilitas yang belum memadai, serta kualifikasi guru yang masih rendah.

Namun dengan berjalannya reformasi terhadap pendidikan Islam dan usaha Al-Washliyah untuk mengembangkan pendidikannya agar tidak lagi kalah bersaing dengan pendidikan lainnya, kini Al-Washliyah sudah cukup terkenal dalam masyarakat luas, dan memiliki daya tarik bagi orang tua yang memperhatikan pendidikan anaknya khususnya pada pendidikan Islam.

Lembaga-lembaga pendidikan yang didirikan oleh organisasi Al-Washliyah telah mengalami perkembangan terutama dari sisi fasilitas, baik dari jumlah unit bangunan sekolah maupun materi pelajaran yang dimiliki pada program pendidikan. Pada masa awal didirikan lembaga pendidikan Al-Washliyah, lebih terfokus kepada pendidikan agama seperti ibtidaiyah, tsanawiyah, dan aliyah. Namun pada periode generasi penerus, Al-Washliyah juga mendirikan lembaga pendidikan umum. UNIVA dan beberapa Sekolah Tinggi yang muncul tidak lagi hanya berkonsentrasi pada fakultas agama, tetapi sudah mengembangkan fakultas umum, seperti yang berada pada Universitas Muslim Nusantara (UMN) Al- 
Washliyah Medan. Universitas ini didirikan setelah Universitas Al-Washliyah (UNIVA).

Sekalipun Al-Washliyah mengelola lembaga-lembaga pendidikan yang sebagiannya disebut sekolah umum, akan tetapi dengan memperhatikan dasar tujuan-tujuan pendidikan yang dikemukakan, disandingkan dengan rekomendasi Konferensi Dunia Pendidikan Islam tahun 1977, yang menyatakan bahwa konsep ilmu dalam Islam tidak membatasi dan menghalangi ilmu-ilmu pengetahuan teoritis, empiris dan terapan sepanjang tidak bertentangan dengan prinsip-prinsip iman (Siddik, 2013:27), maka dapat dikatakan semua lembaga pendidikan yang dikelola oleh Al-Washliyah merupakan lembaga pendidikan Islam.

Berdasarkan latar belakang tersebut, penulis ingin melihat sekaligus memberikan analisis mengenai perkembangan pendidikan pada masa reformasi oleh organisasi Al-Jam'iyatul Washliyah sebagai objek lembaganya. Mengingat organisasi ini, merupakan salah satu organisasi besar Islam di Sumatera Utara. Penelitian ini akan fokus pada perkembangan pendidikan Al-Washliyah di Kota Medan pada masa reformasi.

\section{PEMBAHASAN}

Di Indonesia pendidikan Islam memiliki begitu banyak model pengajaran, baik yang berupa pendidikan sekolah, maupun pendidikan nonformal seperti pengajian, arisan dan sebagainya. Untuk institusi pendidikan lembaga formal dewasa ini adalah sekolah dan madrasah.

Menurut Chadijah Hasan (dalam Hasbullah,2009:149) dunia pendidikan Islam dengan pendidikan umumnya, kadang-kadang memang mempunyai persamaan dan kadang-kadang juga memiliki perbedaan. Persamaan akan timbul karena sama-sama berangkat dari dua arah pendidikan yakni, dari diri manusia sendiri yang memang fitrahnya untuk melakukan proses pendidikan, kemudian dari budaya yakni masyarakat yang memang menginginkan usaha warisan nilai, maka semuanya memerlukan pendidikan. 


\section{A. Sejarah Berdirinya Organisasi Al-Jam'iyatul Washliyah}

Organisasi Al-Jam'iyatul Washliyah merupakan organisasi keagamaan yang turut serta menanamkan sekaligus mengembangkan pendidikan Islam pada masyarakat kota Medan. Menurut Muaz (dalam Dja'far 2013:117), Al-Jamiyatul Washliyah adalah organisasi Islam yang muncul dari kegiatan Ilmiah sejumlah pelajar Sumatera Timur pada era Kolonialisme.

Berdasarkan hasil wawancara dengan bapak Arifin Umar, selaku Wakil Ketua MPPW Al-Washliyah Sumatera Utara (2015-2020), beliau menyatakan bahwa : "Pada saat itu, bangsa Belanda menggunakan perpecahan dan perbedaan sebagai bentuk strategi agar terus berkuasa di Indonesia. Berbagai cara dilakukan oleh pihak Belanda untuk terus mengadu domba masyarakat Indonesia sehingga rakyat terpecah belah. Pihak Belanda sangat khawatir akan kemampuan rakyat Indonesia, terutama jika rakyat mulai melawan dan bersatu. Upaya-upaya perpecahan, salah satunya juga dilakukan dengan masuk pada sendi-sendi ajaran agama Islam. Pada masa itu umat Islam terpecah diakibatkan oleh perbedaan pandangan dalam hal ibadah dan cabang dari agama. Kondisinya terus memburuk hingga umat Islam terbelah menjadi dua kubu, yaitu kaum tua dan kaum muda.Dengan adanya perselisihan ini, kalangan umat Islam di Medan, para pelajar yang belajar di Maktab Islamiyah Tapanuli Medan, berusaha untuk mempersatukan kembali umat Islam yang telah berpecah-belah.”

Burhanuddin (2008:28) menjelaskan bahwa, Al-Jam'iyatul Washliyah dilahirkan untuk bisa menjadi wadah berhimpunnya orang-orang yang memiliki tujuan mulia yaitu membaikkan hubungan manusia dengan Allah (Hablun Minallah) dan hubungan manusia dengan manusia (Hablun Minannas). Dengan demikian organisasi Al-Jam'iyatul Washliyah merupakan salah satu organisasi yang berkembang sesuai dengan tujuan dasar yang bergerak dalam bidang pendidikan, sosial, dan agama yang menghubungkan umat muslim dengan Tuhan yang menciptakan, serta kepada sesama umat manusia. Secara harfiah AlJam'iyatul Washliyah berasal dari dua kata yaitu, Jam 'iyyatun dan Al-Washliyah. Jami'yyatun berarti perkumpulan, perhimpunan, atau persatuan. Sementara itu $A l$ Washliyah memiliki arti penghubung atau menjembatani. Dengan demikian secara 
umum nama Al-Jam'iyatul Washliyah berarti "Perhimpunan yang memperhubungkan atau yang menjembatani”.

\section{B. Pengelolaan Pendidikan Al-Jam'iyatul Washliyah}

Dalam organisasi Al-Washliyah, pengurus dan pengelola yang bertugas dalam bidang pendidikan dinamakan Majelis Pendidikan. Al-Washliyah merupakan organisasi yang memulai gerakannya melalui bidang pendidikan, bahkan ia dibesarkan karena peranannya pada bidang pendidikan. Sehingga program utama yang segera ditangani oleh organisasi ini adalah bidang pendidikan.

Banyaknya jumlah madrasah dan sekolah yang didirikan oleh Al-Washliyah menandakan organisasi ini mudah diterima oleh masyarakat dan telah berperan dalam mencerdaskan bangsa. Dengan jumlah yang terus bertambah dari waktu ke waktu, dibutuhkan pengelolaan dan pengawasan yang lebih profesional. Karena itu keberadaan Majelis Pendidikan Al-Washliyah sangat diperlukan. Pembentukan majelis-majelis pendidikan bersamaan dengan didirikannya pula Al-Washliyah pada tahun 1930, kemudian dilanjutkan pada tahun 1934, setelah terbentuknya struktur Pengurus Besar Al-Washliyah.Terhitung sejak tahun 1934 organisasi AlWashliyah menggerakkan majelis-majelis yang telah disusun, dan sebagai catatan bahwa majelis yang dibentuk pada tahun 1934 itu berbeda dengan majelis yang dibuat pada masa awal berdirinya Al-Washliyah.

Berdasarkan hasil wawancara dengan Bapak Dedi Suhairi selaku Ketua MPPD Kota Medan (2016-2021), beliau menyatakan bahwa : "Salah satu majelis yang dibentuk itu adalah majelis tarbiyah, yaitu majelis yang mengurusi masalah pendidikan dan pengajaran. Majelis atau bidang yang secara khusus mengurusi masalah pendidikan pertama sekali dibentuk pada Konfrensi Al-Washliyah tahun 1934. Semula majelis ini disebut Majelis Pendidikan, Pengajaran dan Kebudayaan (MPPK) atau disebut juga Majelis Tarbiyah Umumi. Perkembangan selanjutnya Majelis Tarbiyah yang bertugas mengelola dan mengurusi masalah pendidikan berubah nama menjadi Majelis Pendidikan Pengajaran dan Kebudayaan (MPPK) Al-Washliyah. Dan pada Muktamar Al Washliyah Ke-18 di Bandung tahun 1997 berubah nama lagi menjadi Majelis Pendidikan dan Kebudayaan (MPK). Dan pada 
Muktamar XX tahun 2010 di Jakarta kembali berubah nama menjadi Majelis Pendidikan, dengan tujuan agar Majelis ini fokus hanya pada aktifitas pendidikan.” Artinya sejak pertama kali dibentuk sampai dengan tahun 2010, Majelis ini terus mengalami perubahan nama. Hingga pada Muktamar XX di Jakarta kembali berubah nama menjadi Majelis Pendidikan saja, dengan tujuan agar majelis ini fokus hanya pada aktifitas pendidikan. Majelis Pendidikan Dasar dan Menengah Al-Washliyah (MPDM PB) Al-Washliyah adalah satu-satunya majelis sebagai pembina, pengelola, dan/atau penyelenggara pendidikan bidang pendidikan dasar dan menengah Al-Washliyah di tingkat Pengurus Besar. Sedangkan Majelis Pendidikan Al-Washliyah (MP) adalah satu satunya majelis sebagai pengelola pendidikan bidang pendidikan dasar dan menengah Al-Washliyah yang berada di tingkat Provinsi (MP Wilayah), Kabupaten/Kota (MP Daerah), dan Kecamatan (MP Cabang).

Disebutkan bahwa tugas Majelis Pendidikan ini adalah mempimpin dan mengatur kesempurnaan jalannya perguruan, pendidikan, pengajaran, dan kebudayaan di dalam segala jenis tingakatan madrasah/perguruan serta pendidikan dasar, lanjutan dan perguruan tinggi, mendirikan madrasah-madrasah, sekolahsekolah, pesantren dan perguruan-perguruan yang bersifat agama dan umum, menyiapkan, menyediakan dan mengangkat tenaga kependidikan (guru dan dosen) yang memiliki kompetensi yang profesional, mengadakan hubungan kerjasama dengan berbagai lembaga dalam maupun luar negeri, berwenang mengangkat dan memberhentikan pimpinan dan tenaga kependidikan di lingkungan satuan pendidikan dalam berbagai jenjang dan jenis, serta mengadakan dan mengusahakan beasiswa.

\section{Tujuan Al-Washliyah dalam Bidang Pendidikan di Kota Medan}

Tujuan umum Pendidikan Al-Washliyah menurut Peraturan Pelaksanaan Sistem Pendidikan Al-Washliyah tahun 2017 adalah :

1. Menghasilkan manusia mukmin yang bertaqwa, berilmu pengetahuan luas dan dalam, berakhlakul karimah, sukses di dunia dan selamat di akhirat. 
2. Mengembangkan dan menyebarkan ilmu pengetahuan, teknologi, dan/atau kesenian serta mengupayakan penggunaannya untuk meningkatkan taraf hidup masyarakat guna mencapai dunia dan akhirat.

3. Menghasilkan Sumber Daya Manusia yang berkualitas kader untuk melanjutkan perjuangan dan amaliyah Al-Washliyah.

4. Menghasilkan lulama dan umara uswatun hasanah yang menjadi panutan umat.

Tujuan pendidikan Al-Washliyah secara khusus dijelaskan dalam Keputusan Pengurus Besar Al-Washliyah Tentang Sistem Pendidikan Al Washliyah Tentang Pendidikan Pra Sekolah, Pendidikan Dasar dan Pendidikan Menengah dalam pasal 2 sebagai berikut:

1. TK Al-Washliyah bertujuan untuk membantu meletakkan dasar ke arah perkembangan sikap, perilaku pengetahuan, keterampilan dan daya cipta yang diperlukan oleh anak didik dalam menyesuaikan diri dengan lingkungannya dan untuk pertumbuhan serta perkembangan selanjutnya.

2. Sekolah Dasar bertujuan memberi bekal kemampuan dasar kepada siswa dalam mengembangkan kehidupannya sebagai pribadi, anggota masyarakat, warga negara, serta mempersiapkan siswa untuk melanjutkan ke sekolah lanjutan tingkat pertama.

3. SLTP bertujuan memberikan bekal kemampuan dasar yang merupakan perluasan serta peningkatan pengetahuan dan keterampilan untuk mengembangkan kehidupannya sebagai pribadi, anggota masyarakat, warga negara sesuai dengan tingkat perkembangannya serta mempersiapkan siswa untuk hidup dalam masyarakat dan mengikuti pendidikan menengah.

4. SMU bertujuan meningkatkan pengetahuan siswa dan melanjutkan pendidikan pada jenjang yang lebih tinggi, mengembangkan diri sejalan dengan perkembangan ilmu pengetahuan, teknologi, dan kesenian serta meningkatkan kemampuan siswa sebagai anggota masyarakat dalam mengadakan hubungan timbal balik dengan lingkungan sosial, budaya, dan alam sekitar. 
5. SMK bertujuan mempersiapkan siswa untuk melanjutkan ke jenjang pendidikan yang lebih tinggi dan meluaskan pendidikan dasar serta meningkatkan kemampuan siswa sebagai anggota masyarakat dalam mengadakan hubungan timbal balik dengan lingkungan sosial, budaya, dan alam sekitar, dan untuk dapat mengembangkan diri sejalan dengan perkembangan ilmu pengetahuan, teknologi dan kesenian serta mempersiapkan siswa untuk memasuki lapangan kerja dan mengembangkan sikap profesional.

\section{Usaha dan Peranan Al-Washliyah dalam Bidang Pendidikan di Kota Medan}

Sejak berdiri, Al-Washliyah memiliki perhatian besar terhadap dunia pendidikan. Sebagai salah satu organisasi pembaharu, Al-Washliyah memainkan peranan tidak kecil bagi perubahan kondisi umat Islam Indonesia. Sebagai organisasi pembaharu pendidikan Islam, Al-Washliyah memiliki komitmen tinggi terhadap pengembangan kualitas pendidikan Indonesia. Dalam Anggaran Dasar dan Anggaran Rumah Tangga Al-Jam'iyatul Washliyah disebutkan bahwa salah satu usaha Al-Washliyah dalam mencapai tujuannya yaitu menegakkan ajaran Islam untuk terciptanya masyarakat yang beriman, bertakwa, cerdas, amanah, adil, makmur dan diridhai Allah Swt, adalah dengan cara mendirikan lembaga-lembaga pendidikan dalam semua jenis pendidikan, serta mengatur kesempurnaan pendidikan dan pengajaran dan kebudayaan.

Dalam Wijhah Al-Washliyah disebutkan bahwa "Al-Washliyah menilai bahwa pendidikan dan pengajaran, adalah unsur mutlak bagi tegak dan teguhnya Islam, merupakan hal yang wajib bagi pria dan wanita.” Dalam buku Kepribadian Anggota dan Pengurus Al-Washliyah disebutkan bahwa "siapa yang memegang pendidikan masa kini, dialah pemimpin hari esok." Disebutkan pula bahwa profesi utama Al-Washliyah adalah "membina intern umat Islam dalam bidang pendidikan, dakwah dan sosial." Secara normatif, Al-Washliyah memiliki semangat tinggi untuk mengembangkan dunia pendidikan. 
Secara tegas komitmen Al-Washliyah dalam dunia pendidikan dapat dilihat dari hasil Muktamar Al-Washliyah XIV di Medan. Dalam Muktamar tersebut, Majelis Pendidikan telah membuat rencana pembangunan Al-Washliyah dalam bidang pendidikan, dan rencana tersebut dibagi menjadi tiga, yakni pendidikan rumah tangga (informal), madrasah/perguruan (formal), dan masyarakat (nonformal).

\section{E. Perkembangan Al-Washliyah dalam Bidang Pendidikan Umum Pada Masa Reformasi di Kota Medan}

Mengingat kebutuhan dan tuntutan umum, khususnya setelah kemerdekaan RI, maka berdirilah beberapa sekolah umum Al-Washliyah seperti SD dan SMP. Pada era Orde Baru, sekitar tahun tujuh puluhan berdiri pula sekolah kejuruan seperti Sekolah Pendidikan Guru (SPG), Sekolah Menengah Ekonomi Atas (SMEA), Sekolah Teknologi Menengah (STM), dan Sekolah Menengah Tingkat Atas (SMA).

Lembaga pendidikan umum oleh Al-Washliyah di Kota Medan mengalami peningkatan. Pada tahun 1998 jumlah lembaga pendidikan umum milik AlWashliyah berjumlah 58 unit, sedangkan pada tahun 2003 dalam kurun waktu 5 tahun sekolah umum Al-Washliyah di Kota Medan bertambah menjadi 63 unit. Pada tahun 2019 bertambah 3 unit. Data tahun 2019 menyebutkan jumlah lembaga pendidikan umum Al-Washliyah di Kota Medan sebanyak 66 unit, serta Pendidikan Tinggi sebanyak 2 unit.

Menurut Peraturan Pelaksanaan Sistem Pendidikan Al-Washliyah bidang Pendidikan Dasar dan Menengah Bab I Pasal 1 tahun 2017 dikatakan bahwa "Sistem Pendidikan Al-Washliyah adalah keseluruhan komponen pendidikan yang saling terkait secara terpadu untuk mencapai tujuan Pendidikan Al-Washliyah dan Pendidikan Nasional.

Mengenai Kurikulum lembaga-lembaga pendidikan Al-Washliyah, dinyatakan oleh bapak Arifin Umar, bahwa :"Dalam bidang pendidikan, selain mengelola lembaga pendidikan agama dengan menggunakan kurikulum Departemen Agama, Pendidikan Al- Washliyah juga mengelola lembaga 
pendidikan umum yang didasarkan pada kurikulum Departemen Pendidikan dan Kebudayaan. Sesuai dengan usaha yang dilakukan Pendidikan Al-Washliyah untuk mewujudkan pembangunan manusia seutuhnya, kurikulum yang digunakan pada Pendidikan Al- Washliyah diarahkan agar sesuai dengan tujuan pendidikan Al-Jam iyatul Al- Washliyah, yakni terwujudnya kesatuan antara pemberian ilmu pengetahuan, agama dan keterampilan."

Mengenai perkembangan kurikulum pada masa reformasi di pendidikan umum ini, dikemukakan oleh Bapak Dedi Suhairi :"Bahwa kurikulum yang ada dibidang pendidikan umum Al-Washliyah ini berkembang sesuai dengan berkembangnya kurikulum dari pemerintah." Artinya kurikulum lembaga pendidikan umum Al-Washliyah seperti TK, SD, SMP, SMU, SMEA DAN STM menggunakan kurikulum Departemen Pendidikan dan Kebudayaan (DEPDIKBUD) dengan menambahkan pelajaran Ke Al-Washliyahan. Untuk kurikulum perguruan tinggi, Al-Washliyah menggunakan kurikulum DEPDIKBUD untuk jurusan umum, dan kurikulum DEPAG untuk jurusan agama dengan menambahkan Sibghah Al-Washliyah.

\section{F. Masalah yang dihadapi Al-Washliyah dalam Mengembangkan Pendidikan di Kota Medan}

Meskipun sudah banyak mendirikan dan mengembangkan lembagalembaga pendidikan, namun tidak bisa dipungkiri bahwa Al-Washliyah juga turut mengalami sejumlah problematika dalam upaya mengembangkan pendidikan di Kota Medan.

Yang menjadi masalah penting adalah sejak tahun 2003, Al-Washliyah belum memiliki data konkrit tentang jumlah pelajar di lingkungan lembagalembaga pendidikan Al-Washliyah. Masalah ini diungkap oleh PD Al-Washliyah (1998-2003) bahwa tidak diketahui secara tepat jumlah siswa disekolah dan madrasah di Kota Medan, karena laporan bulanan yang diberikan kepada pihak skeolah dan madrasah tidak diisi dan dikembalikan kepada pihak PD Al-Washliyah Kota Medan. Padahal laporan bulanan tersebut sangat penting bagi organisasi ini 
dalam rangka mengetahui secara pasti kuantitas siswa-siswa Al-Washliyah di Kota Medan.

\section{PENUTUP}

Tidak hanya mendirikan sekolah yang bercorak agama (madrasah), AlWashliyah juga mendirikan dan mengembangkan sekolah yang bercorak umum. Pendidikan umum Al-Washliyah sendiri baru didirikan pada tahun 1938 namun berkembang pada tahun 90-an dengan tujuan organisasi Al-Washliyah sendiri ingin mempersiapkan anak-anak didik yang berwawasan pengetahuan umum, luas dan dalam, tidak hanya terfokus pada agama saja, namun tetap mengedepankan pengetahuan agama.

Diketahui dari berbagai dokumen dan arsip Al-Washliyah, pada masa reformasi tahun 1998-2019 dalam bidang pendidikan umum, Al-Washliyah mengalami perkembangan dalam bidang pendidikannya baik itu dari jumlah bangunan lembaga pendidikan, fasilitas, dan sistem pendidikan. Pada jenjang pendidikan umum Al-Washliyah membuka dan mengembangkan lembaga pendidikan diantaranya : Taman Kanak-Kanak (TK) pada jenjang pendidikan pra sekolah, Sekolah Dasar (SD) Al-Washliyah pada jenjang pendidikan dasar, Sekolah Menengah Pertama (SMP) Al-Washliyah pada jenjang pendidikan lanjutan, dan jenjang pendidikan menengah terdiri dari dua jenis yaitu : Sekolah Menengah Atas (SMP) Al-Washliyah, dan Sekolah Menengah Kejuruan (SMK) Al-Washliyah. Sementara itu jenjang pendidikan tinggi di Kota Medan diantaranya adalah Universitas Al-Washliyah (UNIVA) dan Universitas Muslim Nusantara (UMN) AlWashliyah.

Berdasarkan data dan laporan dari Majelis Pendidikan Kota medan, lembaga-lembaga pendidikan diatas mengalami perkembangan jumlah unit bangunan sekolah pada masa reformasi dari tahun 1998-2019 dan sarana-prasarana yang sudah cukup memadai. Selain itu, pada tingkat TK, SD, SMP, SMA, dan SMK, Al-Washliyah menggunakan kurikulum dari Departemen Pendidikan Nasional dengan tambahan Sibghah Al-Washliyah. Sedangkan perguruan tinggi umum Al-Washliyah menggunakan kurikulum Departemen Pendidikan Nasional 
dengan menambahkan materi Sibghah Al-Washliyah. Materi pelajaran seperti perguruan tinggi juga mengalami perkembangan, seperti halnya pada UNIVA yang tidak lagi terfokus pada pendidikan agama saja. UNIVA juga mendirikan dan mengembangkan beberapa fakultas umum.

Pendidikan umum Al-Washliyah sampai saat ini, masih terus eksis dan berkembang dikarenakan pendidikannya tidak hanya mempelajari bidang umum namun juga ditambah dengan bidang agama serta nilai-nilai keislaman. Sehingga masyarakat Kota Medan masih mempercayakan Al-Washliyah untuk menjadi tempat mendidik anak-anak mereka dalam dua bidang sekaligus. Namun dalam mengembangkan pendidikan, Al-Washliyah Kota Medan juga memiliki berbagai masalah yang dihadapi. Utamanya, Al-Washliyah belum memiliki data pasti tentang jumlah siswa di lembaga pendidikannya.

\section{Referensi}

Al Butary, Burhanuddin. 2008. Ruh Pengembangan Al-Jam 'iyatul Washliyah. Kisaran: Bunafitas Kisaran.

Hasbullah, 2009. Dasar-dasar pendidikan. Jakarta : Raja Grafindo Persada.

Kep-091/PB-AW/XXIV/2017. Peraturan Pelaksanaan Sistem Pendidikan AlWashliyah Bidang Pendidikan Dasar dan Menengah.

Mukhyar, Ahmad. 2008. Pendidikan Ke Al-Washliyahan 2 : Majelis Pendidikan dan Kebudayaan Al Jam'iyatul Washliyah Sumatera Utara

Mukhyar, Ahmad. 2008. Pendidikan Ke Al-Washliyahan 3 : Majelis Pendidikan dan Kebudayaan Al Jam'iyatul Washliyah Sumatera Utara

Pengurus Besar Al-Jam'iyatul Washliyah. 2003. Anggaran Dasar dan Anggaran Rumah Tangga Al-Jam'iyatul Washliyah Periode 2003-2008. Jakarta : PB Al-Washliyah

Peraturan Pelaksanaan Sistem Pendidikan Al-Washliyah bidang Pendidikan Dasar dan Menengah Bab I Pasal 1 tahun 2017.

Siddik, Dja'far. Rosnita dan Ja'far. 2011 “Lembaga-lembaga Pendidikan AlWashliyah di Sumatera Utara 2000-2010; Eksistensi , Tipologi dan Problematika”. Medan. Pusat Penelitian IAIN Sumatera Utara. 